\title{
Evaluation of the Quality of Academic Programs in Colleges of Applied Studies and Community Services Kingdum of Saudi Arabia
}

\author{
Anas Satti Mohamed \\ Business Administration Department \\ College of Applied Studies and Community Service Imam Abdulrahman Bin Faisal University (KSA 2019) \\ Ghada Mohamed Alhaj \\ Business Administration Department \\ College of Applied Studies and Community Service Imam Abdulrahman Bin Faisal University (KSA 2019)
}

\begin{abstract}
Universities are scientific and educational institutions that aims to achieve many academic, research and community service objectives, the matter that has given it importance in the field of scientific, technological and service development. Because of the open door policy in higher education in many countries, which depends on quantitative and not qualitative expansion, it was always necessary to conduct review of the performance of universities and educational institutions in order to evaluate these institutions and ensure that they meet the quality requirements and standards.

Evaluation of academic programs quality is one of the important contexts that modern research seeks to cover, study, and address. The quality assessment of academic programs enables universities to explore strengths and weaknesses in their academic performance, and provide them with the opportunity to make adjustments and develop plans for change and development based on accurate data analysis. Which contributes to the achievement of the high educational valuable mission and the achievement of academic goals, and deals with the complexities and difficulties associated with academic programs. Moreover, it contributes to highlight the shortcomings areas that require a degree of responsibility and accountability from decision and policy makers. Hence evaluating academic programs will be reflection of the aspirations of the universities (Ali Alqazo.2017)

Based on the Evaluation of the quality of academic programs offered by the Colleges of Applied Studies from the perspective of stakeholders (students, faculty members and employers), this study results prove that academic programs of the faculties of applied studies in Saudi public universities are of medium quality from the students, faculty staff and employers points of view.
\end{abstract}

DOI: $10.7176 / \mathrm{IKM} / 9-3-03$

Publication date:March $31^{\text {st }} 2019$

\section{Research Problem}

The graduates of higher education accept themselves to be qualified and has the capacities that fit the nature of the job and their colleges is responsible of that.

Employers expect colleges to support them by qualified and certified labor force to raise the spirit of competition in human resources by paying attention to quality higher education institutions.

The staff in colleges looks at fair valuation mechanism of students through learning quality and consistent programs and continuous improvement of programs. In general, high quality academic programs can enhance competitive advantages of community services colleges from different points of views. On the other hand

\section{Research questions}

The study try to answer the following questions:

Are the academic programs offered by the faculties of applied studies in Saudi Arabia are of high quality from faculty members point of view?

Are the academic programs offered by the faculties of applied studies in Saudi Arabia are of high quality from students point of view?

Are the academic programs offered by the faculties of applied studies in Saudi Arabia are of high quality from 
employer's point of view?

\section{Purpose of the study}

The study aims to identify the degree of satisfaction of faculty members, students, employers about the quality of the academic programs offered by the faculties of applied studies in order to provide feedback to the decision makers so that they can address the short comings in the light of the results reached.

\section{The importance of studying}

The importance of this study comes from that quality assurance in higher education remains to be one of the most prominent fields of research at the present. Because of increasing competition among higher education institutions and the increasing stakeholders' concentration on preforming and accountability in higher education, Considerable efforts have been made over the past few years to develop an effective national framework for quality assurance. This study its concern with addressing the quality concept, standing on the idea that academic programs in the faculties of applied studies will contribute to improving the quality of the academic programs and improving their quality to suit the developments that serve the Saudi, Arab and international labour market. Furthermore, the study will introduce Specific valuable conclusions and recommendations of for decision makers at the applied colleges on the quality of their academic programs and the possibility of using it in the applied field. In Saudi Arabian setting, there are still no studies conducted on the overall state of higher education quality assurance. Since In Saudi Arabian setting, there are still a few studies conducted on higher education quality assurance, this study is intended to be a start point for coming similar studies in the field.

\section{Study hypotheses}

The hypotheses of the study are as follows:

The academic programs offered by the faculties of applied studies in Saudi Arabia are of high quality from faculty members' point of view.

The academic programs offered by the faculties of applied studies in Saudi Arabia are of high quality from students' point of view.

The academic programs offered by the faculties of applied studies in Saudi Arabia are of high quality from employers' point of view.

\section{Study boundaries and limitations}

Study boundaries: Evaluation of the quality of academic programs in the faculties of applied studies in KSA from the faculty members, students and employers point of view.

Place boundaries: This study was conducted to (faculty members and students), Faculty of Applied Studies and Community Service, Imam Abdul Rahman bin Faisal University, Saudi Arabia, and employers in the Eastern Province

Time Limitation: This study was conducted during the academic year 1439-1440.

\section{Terminology of study}

Colleges of Applied Studies: Colleges award bachelors and diploma degrees in management and commercial sciences (business administration, marketing management, accounting, economics, finance, management information systems)

Academic Program: A distinguished and structured group of courses, which, after graduation, are awarded the academic degree (Diploma, Bachelors), associated with the program.

\section{Theoretical framework and literature review Quality Concept}

The 'race' to set and apply quality systems in the educational started in the late 20th century in countries all over the world (Hidalgo et al., 2011).

Quality is defined as the core element of business strategies and academic research. Quality includes a set of indicators and dimensions (reliability, tangibility, empathy, responsiveness, dependability) that measure 
inputs, how they are addressed and their final outcomes in order to achieve excellence, uniqueness, (Ali Algazo, 2017)

(Michael et al., 1997) stated that "Quality is what the customer says it is, particularly in the case of higher education because the "product" generated by higher education is not a visible, tangible product that can be held, analysed and inspected for defects

The Arab Universities Union defined quality as the integration of features and characteristics of a product or service in such a way as to meet the specific or implicit needs and requirements or the set of characteristics and advantages of an entity that expresses its ability to meet the specific or expected requirements of the beneficiary.

\section{TQM concept}

Is the creation of outstanding culture in performance, where managers and employees work continuously and strive to meet the expectations of customers and beneficiaries, and work properly from the outset with the achievement of quality effectively and in the shortest possible time (Bahjat Attia, 2015)

\section{Quality assessment}

Quality assessment aims to guide performance, work and programs to ensure its quality through the use of quantitative and qualitative measurement systems depends on specific standards which its results help to focus on more reforming and desired change procedures. Quality assessment mission is to enable universities to develop the quality of their academic programs and enhance its Competitiveness, and get its independency through the following dimensions: academic program objectives, structure, content and curriculum of academic programs, inputs, processes and outputs of academic programs that represented by students, description of the learning environment, feasibility of academic programs, quality and efficiency of graduates performance effectiveness of academic programs, faculty members, facilities, services, infrastructure and supervision of academic programs (Ali alghazo, 2017)

\section{Previous studies}

Varlamis \& Apostolakis reviewed the existing standards for evaluation of academic programs, labor market needs and trends in this field, in order to propose global standards for the evaluation of academic programs. Accordingly, they proposed a model for evaluation of academic programs. The model includes number of global standards must be introduced to reach the best design of the program

(Abdelwahhab 2012) conduct an assessment study for academic programs in Sudanese universities. The study attempted to reveal the realistic of academic programs in Sudanese universities in the light of six Edward Deming's quality criteria from the academic staff and top level management points of view. One of the important results of the study is that despite the existence of a specialised unit for the management and quality assurance in Sudanese universities, the universities is not committed to the application of the total quality standards.

(Alhbeeb 2015) conducted a study at the College of Education at King Saud University evaluate the quality of service provided to students and to determine the gap between the students and the quality of the service provided. The study used the descriptive analytical approach. The study sample consisted of 199 students in the Faculty of Education, The results showed that the quality of services was at a high level, and the students 'perceptions were positive whereas services exceeded the students' expectations. The College of Education introduce all the exact academic services through making additional efforts to achieve tangibility, responsiveness, Passion, and ensure the quality of the academic services introduce to the students.

The study of Salih and Sabih (2008) aimed at evaluating the child program in the Faculty of Occupational and Applied Sciences in Gaza from the point of view of female graduate students. The sample consisted of (93) graduates who applied a questionnaire within six dimensions. The results of the study indicated the clarity of the program plan, and that the level of graduated students' satisfaction on the program is high in term of the program majors, staff, teaching and assessment methods, using of new technology and the cooperated management. The most important weaknesses in the program were the lack of library capabilities, the repetition of the contents of some courses in the program, the absence of guidance and advisory and the overcrowding of the academic 
batches.

The Iham Hassan \& Others study aims at measuring the expectations and perceptions of graduate students in the MBA and DBA programs at the University of Khartoum in Sudan in term of quality of service. The most important results of the study is that the graduates' expectations of the actual quality of service received during their studies exceeded the negative gap between expectations and service. The five factors studied are physical facilities, equipment, the staff, courses and communication. They recommended that improving the quality of service helps the university continuity and enhance its chances of competition.

Raad Altaie study(2013) aims at evaluate the quality of programs in the faculties of humanity at the University of Baghdad in Iraq, in the base of concepts and methods adopted in measuring the quality of service and identifying the level of quality of the current teaching process in the programs. One of the study results Was that thr overall level of quality of the humanity colleges higher than the average. Wheresa the variables under studying, its impact on the programs did not achieve a state of high availability, and at its best situation, it exceeded the average. Some of the variables are lower than the average. That are, availability of faculty members, the scientific eligibility of the student and the legal eligibility of the students.

As mentioned above, this study try to insure the quality of applied studies colleges' academic programs from stake holders point of view. In The same context some previous studies e.g Haapakorpi (2011) focused on the Finnish higher educational system found that organizational culture and personal motivation played important roles in quality assurance participation of stakeholders.

\section{Comments about previous studies}

Saleh and Sabehs' study consistent with the current study in presenting the same subject ( evaluation of academic programs from the students point of view) but it differed from the current study in the type of programs and the study society. The current study society includes (faculty membrs, students, and employers)

\section{Procedures of the field study}

Methodology: The researcher used descriptive analytical approach to evaluate the quality of academic programs in the applied colleges, in order to suit the study objectives and questions

The study society: The study society includes the faculty members, students (male and female) in the College of Applied Studies and Community Service, at Imam Abdul Rahman Bin Faisal University, companies, ministries and agencies in the Eastern Region of Saudi Arabia.

Study Sample: The study society includes a randomly selected sample of the faculty members, students (male and female) in the College of Applied Studies and Community Service, at Imam Abdul Rahman Bin Faisal University. companies, ministries and agencies in the Eastern Region of Saudi Arabia. And

\section{Study tools}

To achieve the objectives of the study and answer its questions, and since the study followed the analytical descriptive method, the questionnaire was chosen to collect data, because the questionnaire is a suitable tool to obtain information and facts related to a particular reality. Compared to other methods, questionnaires are a relatively simple way to collect data. The results are easy to process and can provide useful insights into the subject's aspects. Lower rate of bias by researcher as well as respondents (faculty, students, employers)

Questionnaire is suitable to the subject of the study

Questionnaire is suitable to the current study methodology (descriptive analytical approach)

Accordingly, the researcher designed three types of questionnaire to achieve the objectives of the study according to the study target groups

A questionnaire devoted to faculty members

A questionnaire devoted to students

A questionnaire devoted to employers

\section{Constructing Study Tools}

The study tools were designed based on identify the data should be collected which is relevant to the objectives of the study

The nature of the methodology used in the study, which is descriptive analytical approach 
Previous studies that dealt with (evaluation and measurement of academic programs, studies on the design and dissemination of academic programs, and studies on the quality of education)

\section{Description of study tools}

Questionnaire for faculty members: Include one sub-dimension that reflects the quality of the courses presented by applied colleges.

The questionnaire for the students of the applied studies colleges: included four sub-dimensions that reflect the students 'satisfaction with the academic programs in the college, the students' evaluation of the field activities, the suitability of the teaching strategies for the objectives of the programs

Employers' questionnaire: It included three sub-dimensions that reflect the extent to which the graduates match to the requirements of the labour market, the quality of the academic programs from the employers' point of view, the degree of efficiency of the graduate from the employer's point of view.

\section{Validation of study tools}

Reliability of questionnaire: The tools of the study (the questionnaire directed to the faculty members, the questionnaire directed by the students, the questionnaire directed to the employers) were presented to a number of professionals in the field. In light of their opinions recommendations, the researcher prepared the study tools in its final form.

Measuring of reliability: Reliability of questionnaire means that if the questionnaire is redistributed more than once, under the same situations and conditions it will give same results. In other words, the reliability of the questionnaire means that the results of the questionnaire are stable and not significantly, changed if redistributed more than once in the same sample during a certain period.

Reliability of questionnaire was verified through the Alpha Cronbach coefficient as follows:

Measuring the reliability of the faculty members' questionnaire

Table (1) Coefficient of reliability (Alpha Kronbach) of the faculty members' questionnaire

\begin{tabular}{|r|r|r|}
\hline Dimension & Reliability & Validity \\
\hline Quality of courses from the point of view of faculty members & 0.891 & 0.945 \\
\hline
\end{tabular}

Source: Field Study

The coefficient of reliability (Alpha Kronbach) was calculated for each of the elements and paragraphs for each dimension of the questionnaire. This did not increase the total Reliability coefficient. As shown in Table (1), the reliability coefficient (alpha kronbach) is very high. Which reflects the significance of the results that can be obtained by analysing the paragraphs of the questionnaire and that the study tool is characterized by high reliability.

Measuring the reliability of the students' questionnaire:

Table (2) Coefficient of reliability (Alpha Kronbach) students' questionnaire

\begin{tabular}{|l|r|r|}
\hline Dimension & Reliability & Validity \\
\hline Students Satisfaction with Academic Programs & 0.920 & 0.959 \\
\hline Students' Evaluation of Field Activities & 0.948 & 0.974 \\
\hline Fitting of teaching strategies to program objectives & 0.807 & 0.898 \\
\hline Appropriate of courses for program objectives & 0.897 & 0.947 \\
\hline Questionnaire Over all reliability & 0.856 & 0.925 \\
\hline
\end{tabular}

Table(2) Source: Field Study

As shown in table ( 2) above, the coefficient of reliability (Alpha Kronbach) was calculated for every elements and dimension of the questionnaire. This did not increase the overall reliability coefficient. As shown in Table (2), the reliability coefficient (alpha kronbach) is very high. Which reflects the significance of the results that can be obtained by analyzing the paragraphs of the questionnaire and that the study tool is characterized by high reliability.

When the measures has high reliability and internal consistency, researchers should be more confident that the scores represent what they are supposed to. 
Electronic questionnaire was designed by relying on the available sources for designing questionnaires according to the Google site. The questions in the questionnaire were divided into two models. The student's ID was used as a variable for indexing in both models.

Measuring the reliability of the employers' questionnaire:

Table (3) Coefficient of reliability (Alpha Kronbach) employers' questionnaire

\begin{tabular}{|l|c|c|}
\hline Dimension & Reliability & Validity \\
\hline The degree to which the graduates are reach to the labor market requirements & 0.945 & 0.901 \\
\hline Quality of academic programs from the employers point of view & 0.875 & 0.898 \\
\hline The efficiency of the graduate from the employers point of view & 0.805 & 0.932 \\
\hline
\end{tabular}

Source: Field Study

It is clear from Table (3) that the value of the coefficient of reliability (Alfa Cronbach) for all dimensions, which indicates that the instrument of study is very reliable, which makes us fully confident in the validity of the questionnaire and the validity of analysis and interpretation of the results of the study.

Inter-rater reliability (faculty members, students and emoloyers) is the extent to which different observers are consistent in their judgments

Table (4) Correlation coefficient between main and sub dimension of the study

\begin{tabular}{|c|c|c|c|c|}
\hline $\begin{array}{l}\text { Types of } \\
\text { questionnaire }\end{array}$ & $\begin{array}{l}\text { Main Dimensions of } \\
\text { questionnaire }\end{array}$ & $\begin{array}{ll}\text { Sub } & \text {-dimensions } \\
\text { questionnaire } & \text { of }\end{array}$ & $\begin{array}{l}\text { Correlation } \\
\text { coefficient }\end{array}$ & $\begin{array}{r}\text { Level of } \\
\text { significance }\end{array}$ \\
\hline $\begin{array}{l}\text { Faculty members } \\
\text { questionnaire }\end{array}$ & $\begin{array}{l}\text { Quality of academic } \\
\text { program from } \\
\text { faculty members } \\
\text { point of view }\end{array}$ & Quality of courses & 0.857 & 0.000 \\
\hline \multirow[t]{4}{*}{$\begin{array}{l}\text { Students } \\
\text { questionnaire }\end{array}$} & \multirow{4}{*}{$\begin{array}{l}\text { Quality of academic } \\
\text { program } \\
\text { students point of } \\
\text { view }\end{array}$} & $\begin{array}{l}\text { Students Satisfaction with } \\
\text { Academic Programs }\end{array}$ & 0.781 & 0.000 \\
\hline & & $\begin{array}{l}\text { Students' Evaluation of Field } \\
\text { Activities }\end{array}$ & 0.876 & 0.000 \\
\hline & & $\begin{array}{l}\text { Fitting of teaching strategies to } \\
\text { program objectives }\end{array}$ & 0.789 & 0.000 \\
\hline & & $\begin{array}{l}\text { Appropriate of courses for } \\
\text { program objectives }\end{array}$ & 0.794 & 0.000 \\
\hline \multirow[t]{3}{*}{$\begin{array}{l}\text { Employers } \\
\text { questionnaire }\end{array}$} & \multirow{3}{*}{$\begin{array}{l}\text { Quality of academic } \\
\text { program } \\
\text { employers point of } \\
\text { view }\end{array}$} & $\begin{array}{l}\text { The degree to which the } \\
\text { graduates are reach to the } \\
\text { labour market requirements }\end{array}$ & 0.831 & 0.000 \\
\hline & & $\begin{array}{l}\text { Quality of academic programs } \\
\text { from the employers point of } \\
\text { view }\end{array}$ & 0.848 & 0.000 \\
\hline & & $\begin{array}{l}\text { The efficiency of the graduate } \\
\text { from the employers point of } \\
\text { view }\end{array}$ & 0.858 & 0.000 \\
\hline
\end{tabular}

Source: Field Study

As shown in table (4), the level of significance of all dimension elements is $(0.000)$ at $(0.01)$ sig level. That is indicate the three main dimensions of the study are valid and of high Inter-rater reliability.

Questionnaires devoted to study sample:

Faculty members' questionnaire 
Table (5) shows Questionnaires devoted to faculty members based on academic department and gender

\begin{tabular}{|c|c|c|c|c|c|c|c|}
\hline \multirow[t]{2}{*}{ Gender } & & & & & \multicolumn{2}{|c|}{ Academic department } & \multirow[t]{2}{*}{ Total } \\
\hline & $\begin{array}{r}\text { Business } \\
\text { administration }\end{array}$ & $\begin{array}{r}\text { Marketin } \\
\mathrm{g}\end{array}$ & $\begin{array}{r}\text { Accountin } \\
\mathrm{g}\end{array}$ & $\begin{array}{r}\text { Financial } \\
\text { Sciences }\end{array}$ & $\begin{array}{l}\text { General } \\
\text { courses }\end{array}$ & $\begin{array}{r}\text { Informatio } \\
\mathrm{n} \\
\text { Systems }\end{array}$ & \\
\hline \multirow[t]{2}{*}{ Female } & 4 & 3 & 9 & 2 & 8 & 2 & 28 \\
\hline & $14.29 \%$ & $\% 10.71$ & $32.14 \%$ & $7.14 \%$ & $28.57 \%$ & $7.14 \%$ & $46.67 \%$ \\
\hline \multirow[t]{2}{*}{ Male } & 2 & 2 & 5 & 5 & 14 & 4 & 32 \\
\hline & $6.25 \%$ & $6.25 \%$ & $15.63 \%$ & $15.63 \%$ & $43.75 \%$ & $12.50 \%$ & $53.33 \%$ \\
\hline \multirow[t]{2}{*}{$\begin{array}{l}\text { Grand } \\
\text { Total }\end{array}$} & 6 & 5 & 14 & 7 & 22 & 6 & 60 \\
\hline & $10.00 \%$ & $8.33 \%$ & $23.33 \%$ & $11.67 \%$ & $36.67 \%$ & $10.00 \%$ & $\begin{array}{r}100.00 \\
\%\end{array}$ \\
\hline
\end{tabular}

Source: Field Study

Electronic questionnaires were distributed to faculty members in the college. 60 questionnaires returned back and 59 were analysed.

Students' questionnaire

Table (6) shows Questionnaires devoted to students based on academic department and gender

\begin{tabular}{|c|c|c|c|c|c|c|c|}
\hline \multirow[t]{2}{*}{ Gender } & & & & & \multicolumn{2}{|c|}{ Academic department } & \multirow[t]{2}{*}{ Total } \\
\hline & $\begin{array}{r}\text { Business } \\
\text { administration }\end{array}$ & $\begin{array}{r}\text { Marketi } \\
\text { ng }\end{array}$ & $\begin{array}{r}\text { Accounti } \\
n g\end{array}$ & $\begin{array}{r}\text { Financial } \\
\text { Sciences }\end{array}$ & $\begin{array}{r}\text { Not yet } \\
\text { specialised }\end{array}$ & نظم معلمات & \\
\hline \multirow[t]{2}{*}{ Female } & 114 & 74 & & 25 & 205 & 44 & 462 \\
\hline & $24.68 \%$ & $16.02 \%$ & $0.00 \%$ & $5.41 \%$ & $44.37 \%$ & $9.52 \%$ & $\begin{array}{r}72.87 \\
\%\end{array}$ \\
\hline \multirow[t]{2}{*}{ Male } & 34 & & 36 & 36 & 66 & & 172 \\
\hline & $19.77 \%$ & $0.00 \%$ & $20.93 \%$ & $20.93 \%$ & $38.37 \%$ & $0.00 \%$ & $\begin{array}{r}27.13 \\
\%\end{array}$ \\
\hline \multirow{2}{*}{$\begin{array}{r}\text { Grand } \\
\text { Total }\end{array}$} & 148 & 74 & 36 & 61 & 271 & 44 & 634 \\
\hline & $23.34 \%$ & $11.67 \%$ & $5.68 \%$ & $9.62 \%$ & $42.74 \%$ & $6.94 \%$ & $\begin{array}{r}100.00 \\
\%\end{array}$ \\
\hline
\end{tabular}

Table (6) Source: Field Study

Table (7) shows Questionnaires devoted to employers based on employers department and gender

\begin{tabular}{|c|c|c|c|c|c|c|c|}
\hline \multirow[b]{2}{*}{ Sector } & \multicolumn{6}{|r|}{ specialization } & \multirow[b]{2}{*}{ Total } \\
\hline & $\begin{array}{r}\text { Business } \\
\text { administration }\end{array}$ & Marketing & $\begin{array}{r}\text { Management } \\
\text { systems }\end{array}$ & Accounting & $\begin{array}{r}\text { Financial } \\
\text { management }\end{array}$ & $\begin{array}{r}\text { More than } \\
\text { one } \\
\text { specialization }\end{array}$ & \\
\hline Public sector & 3 & & & 2 & & 6 & 11 \\
\hline $\begin{array}{r}\text { Private } \\
\text { sector }\end{array}$ & 11 & & & 3 & 2 & 14 & 32 \\
\hline Total & 14 & & & 5 & 2 & 20 & 41 \\
\hline
\end{tabular}

Table (7) Source: Field Study

Paper and electronic questionnaire, were distributed to employers in both private and public sectors. The number of paper questionnaires distributed to employers was 23, while the number of electronic questionnaires was 18 . All the 41 were subject to statistical analysis.

\section{Results analysis and interpretation:}

Question 1: Do the academic programs provided by the faculties of applied studies in Saudi Arabia have quality the faculty members' point of view?

In order to answer this question, the arithmetical means and standard deviations were calculated for the sample 
of the study on the indicators of the first dimension (the quality of the courses from the faculty members' view), which included one sub-dimension and (5) indicators. Table (8)

Table (8) The sub-dimention of the questionnaire of faculty members (quality of courses)

\begin{tabular}{|c|c|c|c|c|}
\hline No & First sub-Dimension and its indicators & $\begin{array}{l}\text { The } \\
\text { mean }\end{array}$ & $\begin{array}{l}\text { Standard } \\
\text { deviation }\end{array}$ & Result \\
\hline 1 & $\begin{array}{r}\text { Academic program courses are sufficient to qualify students for the } \\
\text { job market }\end{array}$ & 3.63 & 0.96 & Agree \\
\hline 2 & $\begin{array}{r}\text { The contents of each course take into account recent developments } \\
\text { in the fields of knowledge }\end{array}$ & 3.55 & 0.95 & Agree \\
\hline 3 & $\begin{array}{r}\text { The teaching plan is accompanied by recent developments in the } \\
\text { field of specialization }\end{array}$ & 3.60 & 0.92 & Agree \\
\hline 4 & The department develops its study plans at appropriate intervals & 3.77 & 0.99 & Agree \\
\hline 5 & I am generally satisfied with the quality of courses & 3.78 & 0.88 & Agree \\
\hline 6 & Over all mean and STD & 3.67 & 0.94 & Agree \\
\hline
\end{tabular}

Source: Field Study

Table(8) represents overall means and standard deviations to faculty members' responsiveness about quality of courses introduced by faculty colleges. The means of questions are $(3.63,3.55,3.60,3.77,3.78)$ respectively. The results of this dimension indicates that:

The weighted average of course quality is (3.67) and standard deviation is (0.94), which represents a moderate level of agreement.

The indicator that states (I am generally satisfied with the quality of courses) has the highest weighted mean (3.78) with a standard deviation (0.88), while the indicator states (the contents of each course take into account recent developments in the fields of knowledge) On a weighted average (3.55) with a standard deviation(0.95) has the lowest

There are no indicators in this dimension got weak evaluation or an unreached score

The overall indicators of this dimension tend to have a moderate degree of achievement.

Question 2: Are the academic programs offered by the faculties of applied studies in Saudi Arabia are of high quality from students' point of view. In order to answer this question, the arithmetical means and standard deviations were calculated for the of sample of the study on the indicators of the four indicators of the dimension of the quality of academic programs from students point of view.

In Table 9, which represents the weighted averages and standard deviations of students' responses to student satisfaction with academic programs, the weighted averages are as follows:

$(3.95,3.95,3.74,3.87,4.03,3.71,3.92,3.99,3.66,3.71,3.51,3.76)$ respectively. These results can be concluded as follows:

The weighted average for student satisfaction to academic programs was 3.75 with a standard deviation of 0.98 , which is a moderate agreement degree

The indicator of (what I learn in this program is important to my future) has the highest weighted mean (4.03) with a standard deviation $(0.94)$

The indicator, which states (Feedback from students about the courses (recommendations) is taken in to account), has the lowest weighted mean (3.51) with a standard deviation (1.13)

None of the indicators in tis dimension (the extent to which the graduates are suited to the needs of the labor market) received a low degree of acceptance

The results shows that all indicators of this dimension reflect the general satisfaction of students with the academic programs offered by the applied college, the researcher suggested that this result is due to the nature and diversity of academic programs. 
Table (9) The first sub- dimension of the student questionnaire: Student satisfaction with the programs quality at the applied studies colleges.

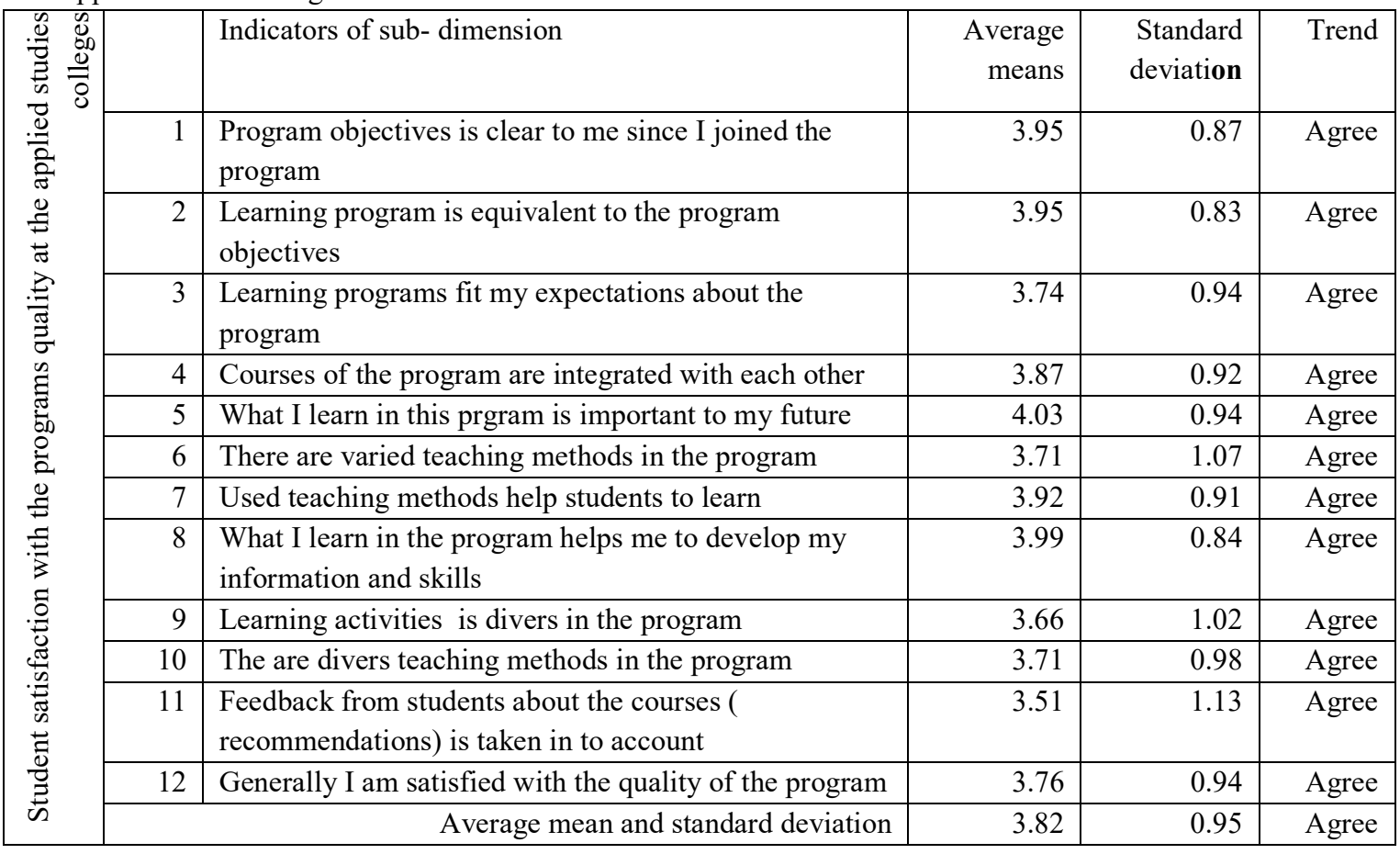

Table (10) The second sub-dimension of the student questionnaire: Student assessment of field activities

\begin{tabular}{|c|c|c|c|c|}
\hline \multirow{4}{*}{ 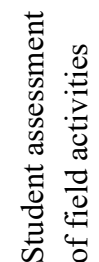 } & Indicators of second sub-dimension & $\begin{array}{l}\text { Weighted } \\
\text { average }\end{array}$ & $\begin{array}{l}\text { Standard } \\
\text { deviation }\end{array}$ & Result \\
\hline & $\begin{array}{l}\text { I am generally satisfied with the quality level of field activities ( } \\
\text { Field visits to companies, factories and Public institutions) }\end{array}$ & 3.99 & 0.84 & Agree \\
\hline & Practical training course is in the suitable academic level & 3.52 & 1.12 & Agree \\
\hline & Weighted average and standard deviation & 3.52 & 1.07 & Agree \\
\hline
\end{tabular}

Source: Field study

Table (10), which represents the weighted averages and standard deviations of students' responses to (field activities evaluation), shows that the values of the arithmetical average of this dimension are as follows (3.99, 3.52) respectively.

The overall weighted average of the dimension was (3.52) with a standard deviation (1.07), which represents the overall average achievement.

The results indicate that the indicators reflect students' general satisfaction with the quality of field activities

Table (11) Third sub-dimension of the student questionnaire: Fit the teaching strategies to objectives of the program

\begin{tabular}{|c|c|c|c|c|}
\hline$\cdot \mathscr{D}_{0}^{\infty}$ & Indicators of the third sub- dimension & $\begin{array}{l}\text { Weighted } \\
\text { average }\end{array}$ & Standard deviation & Result \\
\hline 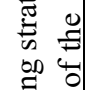 & $\begin{array}{l}\text { Teaching methods helps students to introduce their } \\
\text { ideas and opinions. }\end{array}$ & 3.91 & 0.91 & Agree \\
\hline 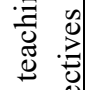 & $\begin{array}{l}\text { Faculty member uses diverse methods in teaching } \\
\text { process }\end{array}$ & 3.61 & 1.08 & Agree \\
\hline 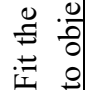 & Weighted average and Standard deviation & 3.76 & 0.98 & \\
\hline
\end{tabular}

Source: Field study

Table 11 shows the weighted averages and standard deviations of students' responses to (fit for teaching 
strategies and program objectives) that the arithmetical mean values for this dimension are as follows (3.91, 3.61), respectively, and we derive the following:

The overall weighted average to fit the teaching strategies and objectives of the program (3.76) at a standard deviation (0.98), which represents a moderate approval achievement.

Students agree that teaching methods help students to introduce their views and ideas

The dimension (the number of faculty members in methods used in the teaching process) has a weighted average (3.61) with a standard deviation (1.08). It represents the average approval score on the dimension.

Table (12) The fourth sub-dimension of the student questionnaire: the suitability of the courses to the objectives of the program

\begin{tabular}{|c|c|c|c|c|}
\hline \multirow{3}{*}{ 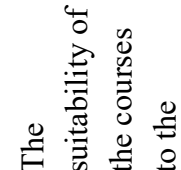 } & The fourth sub-dimension indicators & $\begin{array}{l}\text { Weighted } \\
\text { average }\end{array}$ & $\begin{array}{l}\text { Standard } \\
\text { deviation }\end{array}$ & Result \\
\hline & The courses is suitable to the program objectives. & 3.87 & 0.86 & Agree \\
\hline & Weighted average and standard deviation & 3.87 & 0.86 & Agree \\
\hline
\end{tabular}

Source: Field study

Table (12) shows that the index, which states (the adequacy of courses to achieve program objectives) has a weighted average of (3.87), which represents a moderate degree of agreement.

Question 3: Do the academic programs introduced by the colleges of applied studies in Saudi Arabia have the quality fro the employer's point of view? In order to answer this question, the arithmetical averages and standard deviations were calculated for the sample of the study. The dimension are (quality of the academic programs from the employers point of view), which included 3 sub-dimension, (18) indicators and tables (13), (14) and (15) shows the results associated with this question.

Table (13) first Sub-dimension for mployers' questionnaire: the extent to which the graduates are suited to the needs of the labor market

\begin{tabular}{|c|c|c|c|c|}
\hline \multirow{8}{*}{ 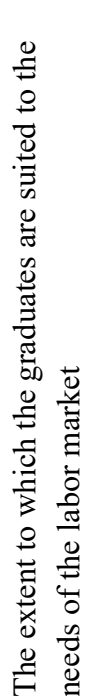 } & Indicators of the first sub dimension & $\begin{array}{l}\text { Weighted } \\
\text { average }\end{array}$ & $\begin{array}{l}\text { Standard } \\
\text { deviation }\end{array}$ & Result \\
\hline & $\begin{array}{l}\text { The graduate can exercise his tasks assigned to him } \\
\text { efficiently. }\end{array}$ & 4.414 & 0.59 & $\begin{array}{l}\text { Completely } \\
\text { agree }\end{array}$ \\
\hline & Graduates adapt to their new career quickly & 4.268 & 0.707 & $\begin{array}{l}\text { Completely } \\
\text { agree }\end{array}$ \\
\hline & $\begin{array}{l}\text { The graduate uses innovative methods and ways to } \\
\text { accomplish tasks }\end{array}$ & 4.00 & 0.774 & Agree \\
\hline & $\begin{array}{l}\text { The theoretical knowledge of the graduate is clearly appear } \\
\text { during professional practices }\end{array}$ & 4.219 & 0.612 & $\begin{array}{l}\text { Completely } \\
\text { agree }\end{array}$ \\
\hline & The graduate seeks to develop himself & 4.39 & 0.666 & $\begin{array}{l}\text { Completely } \\
\text { agree }\end{array}$ \\
\hline & $\begin{array}{l}\text { The graduate is committed to performing the tasks assigned } \\
\text { to him on time }\end{array}$ & 4.243 & 0.942 & $\begin{array}{l}\text { Completely } \\
\text { agree }\end{array}$ \\
\hline & Weighted average and standard deviation & 4.256 & 0.544 & $\begin{array}{l}\text { Completely } \\
\text { agree }\end{array}$ \\
\hline
\end{tabular}

Source: Field study

Table (13) shows the weighted averages and standard deviations of employers' responses to the extent to which the graduates fit the needs of the labor market. The weighted averages are as follows: $(4.414,4.268,4.00,4.219$, $4.39,4.243$, and 4.243) for each question respectively.

The weighted average age of the graduate's suitability for labor market needs was (4.256) with a standard deviation of (0.544) which represents a high degree of approval.

The indicator, which states: (A graduate of the college can perform the tasks assigned to him efficiently) received the highest weighted average of (4.414) with a standard deviation (0.59). While Indicator (3), which states that (the graduate uses creative methods and innovative methods of performing tasks), has the lowest weighted average mean (4.00) with a standard deviation (0.774), which is the only indicator with a moderate 
aceptance degree.

None of the pivotal indicators (the extent to which the graduates are suited to the needs of the labor market has received a poor degree of acceptance.

The results of the indicators of this dimension indicate that the skills of graduates of the applied colleges fit the needs of the labor market.

Table (14) the second sub-dimension of the employers questionnaire: the quality of the programs from the employers point of view

\begin{tabular}{|c|c|c|c|c|}
\hline$\stackrel{\mathscr{g}}{\rightleftarrows}$ & Indicators of the second sub dimension & $\begin{array}{l}\text { Weighted } \\
\text { average }\end{array}$ & $\begin{array}{l}\text { Standard } \\
\text { deviation }\end{array}$ & Result \\
\hline 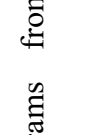 & $\begin{array}{l}\text { The academic study that the graduate has } \\
\text { acquired, develops his skills in the use of } \\
\text { information technology }\end{array}$ & 4.268 & 0.707 & $\begin{array}{l}\text { Completely } \\
\text { agree }\end{array}$ \\
\hline 范 & $\begin{array}{l}\text { The academic study that the graduate received } \\
\text { supports his skills in problem solving and } \\
\text { decision-making }\end{array}$ & 4.146 & 0.853 & Agree \\
\hline 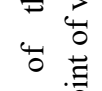 & $\begin{array}{l}\text { The academic study gained by the graduate } \\
\text { enhances his leadership and teamwork skills }\end{array}$ & 4.097 & 0.945 & Agree \\
\hline 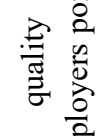 & $\begin{array}{l}\text { The academic study obtained by the graduate } \\
\text { develops his managerial skills (planning, } \\
\text { organizing, controlling, and directing) }\end{array}$ & 4.097 & 0.888 & Agree \\
\hline$\stackrel{\Xi}{\Xi}$ & Weighted average and standard deviation & 4.152 & 0.677 & Agree \\
\hline
\end{tabular}

Source: Field study

Table 14 shows the weighted averages and standard deviations of employers' responses to the quality of academic programs offered by the College of Applied Studies and Community Service. It is clear that the weighted averages are as follows: $(4.268,4.146,4.097,4.097)$ that

The general weighted average of the dimension (the quality of programs from the employers' point of view) was (4.152) with a standard deviation (0.677), which in total represents a moderate degree of acceptance.

The first indicator, which states: (The academic study that the graduate obtained his skills in the use of information technology) obtained the highest weighted average of (4.268) with a standard deviation) 0.707 (

The indicators that received a moderate approval in this dimension are the first three oneswith an average mean of $(4.146,4.097,4.097)$, respectively

None of the indicators of the sub- dimension (program quality from employers' point of view) has a poor degree of acceptance.

Results of the indicators of this sub-dimension indicate that the programs of the colleges of applied studies are of medium quality from the employers' point of view.

The weighted averages for the indicators of this sub- dimension are $(4.27,4.29,4.44,44.12,4.20,4.51,4.39$ and 4.27) respectively It follows from this that

The general weighted average of the sub dimension (for the efficiency of the graduate from the employers' point of view) was (4.31) with a standard deviation (0.514) which represents a very high degree of verification

The indicator, which states: (The graduate is committed to job regulations.), has the highest weighted average of 4.51 with a standard deviation 0.736

All indicators of this sub dimension obtained a high degree of acceptance

The indicators that received the lowest level of agreement is the one which states (The graduate possess knowledge and information necessary to perform the tasks) of 4.12 weighted average and 0.812 standard deviation.

None of the indicators of the sub dimension (the degree of efficiency of the graduate from the perspective of employers) has received a poor degree of acceptance..

The results of the indicators of this axis indicate that the graduate of the colleges of applied studies is highly efficient from the employers' point of view. 
Table (15) third Sub-dimension of Employers' questionnaire: the degree of efficiency of the graduate from the employers point of view

\begin{tabular}{|c|c|c|c|c|}
\hline$\cdot \frac{3}{0} \cdot \frac{3}{0}$ & Indicators of the third sub dimension & $\begin{array}{r}\text { Weighted } \\
\text { average }\end{array}$ & $\begin{array}{r}\text { Standard } \\
\text { deviation }\end{array}$ & Result \\
\hline$\stackrel{0}{0}_{0}^{0}$ & $\begin{array}{l}\text { The graduate match le level of quality required in } \\
\text { your organization }\end{array}$ & 4.27 & 0.672 & $\begin{array}{r}\text { Completely } \\
\text { agree }\end{array}$ \\
\hline $\begin{array}{l}\text { Ẽ } \\
\stackrel{\Xi}{\rightleftarrows}\end{array}$ & $\begin{array}{l}\text { The graduate possess technical skills necessary to } \\
\text { perform the work }\end{array}$ & 4.29 & 0.642 & $\begin{array}{r}\text { Completely } \\
\text { agree }\end{array}$ \\
\hline$\underset{0}{\Xi}$ & The graduate can do the tasks assigned to him & 4.44 & 0.594 & $\begin{array}{r}\text { Completely } \\
\text { agree }\end{array}$ \\
\hline 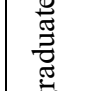 & $\begin{array}{l}\text { The graduate possess knowledge and information } \\
\text { necessary to perform the tasks }\end{array}$ & 4.12 & 0.812 & Agree \\
\hline$\stackrel{\infty}{ \pm}$ & Graduate can overcome work obstacles & 4.20 & 0.679 & $\begin{array}{r}\text { Completely } \\
\text { agree }\end{array}$ \\
\hline 를 & The graduate is committed to job regulations. & 4.51 & 0.736 & $\begin{array}{r}\text { Completely } \\
\text { agree }\end{array}$ \\
\hline 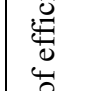 & The graduate is skilful in doing the job & 4.39 & 0.666 & $\begin{array}{r}\text { Completely } \\
\text { agree }\end{array}$ \\
\hline$\underset{\circlearrowright}{0}$ & $\begin{array}{l}\text { The graduate match the requirements of labor } \\
\text { market. }\end{array}$ & 4.27 & 0.633 & $\begin{array}{r}\text { Completely } \\
\text { agree }\end{array}$ \\
\hline $\begin{array}{l}\text { D } \\
\mathscr{E}\end{array}$ & Weighted average and standard deviation & 4.31 & 0.514 & $\begin{array}{r}\text { Completely } \\
\text { agree }\end{array}$ \\
\hline
\end{tabular}

Source: Field study

\section{Conclusion and Results:}

The study aimed at measuring the quality of the academic programs offered by the applied colleges in Saudi universities, from the f faculty members, students, students and employers point of view. The study concluded with a set of results derived from the analysis of the data, and also concluded some recommendations that contribute to increase the quality of academic programs.

The main results of this study are summarized in the following points

The academic programs of the faculties of applied studies are of medium quality from the point of view of faculty members

The academic programs of the colleges of applied studies are characterized by medium quality from the students' point of view

The academic programs of the colleges of applied studies are of medium quality from the employers' point of view of

The courses of the programs of the applied studies colleges are characterized by a medium quality from the faculty members' point of view.

The activities of the field of applied studies are characterized by medium quality

Teaching methods used by faculty members in applied colleges help students to present their ideas and opinions freely.

The faculty member of applied colleges uses different and innovative teaching methods

Students believe that courses achieve the objectives of academic programs.

Graduates of applied colleges can successfully perform the tasks and tasks assigned to them.

Graduates of applied colleges use innovative methods and innovative ways to carry out tasks.

Graduate of Applied Colleges seeks to develop himself.

The graduates of the applied colleges have the knowledge and information necessary to perform the required tasks.

Graduates of applied colleges are suited to the requirements and needs of the labour market. 


\section{Recommendations}

Improving the quality of academic programs to suit the requirements of the labor market

Improve the quality of academic programs to achieve the aspirations of stakeholders

Evaluate the structure of the study plans in proportion to the academic programs

Improve the nature of support services provided by the college and the need to upgrade them to serve the needs of students

Provide training courses for faculty members in the field of teaching methods and the use of modern techniques in teaching

Implementing self-evaluation periodically for all academic programs and providing specific means to measure the satisfaction of students, and also involve students in the evaluation processes and the diversification of assessment methods

Encourage, develop the creativity of students, and provide adequate financial support for the dissemination of such innovations in international journals.

\section{References:}

\section{Arabic references}

Algazo, Ali Mohamed, Al-Qar'an Mahmoud Faisal, 2017, Evaluation of the Quality of Academic Programs at Yarmouk University from the Students' point of view, Islamic University of Gaza, vol. 25, no. 4, pp. 390418

Bahgat, Attia Radi, Al Arabi Hisham Youssef (2015), Total Quality Management, Concept, Philosophy and Applications, Al-Shafri Library for Publishing and Distribution, Saudi Arabia

Al-Taei Raad et al., Evaluation of the quality of human studies programs at the University of Baghdad in light of some factors affecting it, the Arab Journal for Quality Assurance of University Education, No. 11, 2013

Saleh Najwa, Subaih Lina, (2008), Evaluation of the Child Education Program in the Faculty of Occupational and Applied Sciences from the perspective of female students, Islamic University Journal, Human Studies Series

Abdul Wahab, Faisal Mohammed et al., An Assessment Study of the Education System in Sudan, in the light of E, Deming's Quality Standards of Quality Assurance, Second International Conference for Quality Assurance of Higher Education, Union of Arab Universities in coordination with the Gulf University, Manama, Bahrain

\section{English references}

Haapakorpi, A. (2011). Quality assurance processes in Finnish universities: Direct and indirect outcomes and organisational conditions. Quality in Higher Education, 17(1), 69-81.

Hidalgo, E., Villoriaa, J., and Romero-Cerezo, C. (2011) The necessity and challenge of setting up a quality assurance system in the higher education system in Andalusia (Spain). Procedia Social and Behavioral Sciences 15(2011): pp.2972-2976.

Iham Hassan \& Others, Graduate Students' Assessment of Proceedings of the International Arab Conference on Quality Assurance in

Michael, R., Sower, V., and Motwani, J. (1997) A comprehensive model for implementing total quality management in higher education. Benchmarking for Quality Management \& Technology 4(2): pp.104-120.

Varlamis, I., \& Apostolakis, I. (2006). The present and future of standards for E-Learning Technologies Interdisciplinary Journal of knowledge and learning Objects, 2, 59-76 Retrieved form. 